\title{
The Relationship Of Nutritional Status With The Incidence Of Acute Respiratory Tract Infections In Toodlers At Clinics Mekarwangi Garut 2018
}

\section{Hubungan Status Gizi Dengan Kejadian Infeksi Saluran Pernapasan Akut (ISPA) Pada Balita Di Puskesmas Mekarwangi Garut Tahun 2018}

Sulastini Sulastini ${ }^{1}$, Sri Yekti Widadi ${ }^{1}$, Desi Sentia ${ }^{1}$, Bambang Aditya Nugraha $^{2}$

\section{Abstract}

Acute respiratory tract infections is an acute infection caused by viruses, fungi and bacteria. Acute respiratory tract infections cases in Indonesia still rank first with a prevalence of $25 \%$ with malnutrition morbidity of $14.9 \%$. In Garut District, the highest incidence of ARI was in Mekarwangi Health Center as many as 8004 cases and in 1840 children under five. While the prevalence of malnutrition or (thin) as many as 104 cases and 1 case of malnutrition. Nutritional status is a state of the body as a result of food consumption and use of nutrients. Differentiated between thin nutritional status, very thin, normal nutrition and fat nutrition. Nutritional status is one of the factors that play an important role in the health of children under five. If the nutritional status of under-fives or (underweight) toddlers will be susceptible to diseases, especially infectious diseases. The general objective of this study was to determine the relationship of nutritional status with the incidence of ARI in infants in Mekarwangi Garut Health Center in 2018.

The type of research used was descriptive correlative, with a case control approach, a sample of 114 respondents divided into 57 case groups and 57 control groups. bivariate test analysis using chi-square.

The results of the research on the nutritional status of most underweight children and half of children under five experienced acute respiratory tract infections.

Conclusion there is a relationship between nutritional status with acute respiratory tract infections in infants in Mekarwangi Garut Public Health Center in 2018. It is recommended that health workers improve counseling to the public about the factors that affect acute respiratory tract infections in order to be able to overcome and prevent, especially the problem of nutrition improvement.

Keywords: Acute respiratory tract infections, Nutritional Status, Toodler

Afiliasi Penulis

1 | STIKes Karsa Husada Garut

2 | Universitas Padjajaran Bandung

Korespondensi kepada

Sulastini

sulastini26@gmail.com 


\section{Intisari}

ISPA adalah penyakit Infeksi akut yang disebabkan oleh virus, jamur dan bakteri. Kasus ISPA di Indonesia masih menempati urutan pertama dengan prevalensi $25 \%$ dengan morbiditas gizi kurang $14,9 \%$. Di Kabupaten Garut kejadian ISPA terbanyak terdapat di Puskesmas Mekarwangi sebanyak 8004 kasus dan pada balita sebanyak 1840 kasus. Sedangkan prevalensi gizi kurang atau (kurus) sebanyak 104 kasus dan 1 kasus gizi buruk. Status gizi merupakan keadaan tubuh sebagai akibat konsumsi makanan dan penggunaan zat-zat gizi. Dibedakan antara status gizi kurus, sangat kurus, gizi normal dan gizi gemuk. Status gizi merupakan salah satu faktor yang berperan penting terhadap kesehatan balita. Apabila status gizi balita kurang atau (kurus) balita akan mudah terserang penyakit, terutama penyakit infeksi. Tujuan umum dari penelitian ini adalah untuk mengetahui hubungan status gizi dengan kejadian ISPA pada balita di Puskesmas Mekarwangi Garut Tahun 2018.

Jenis penelitian yang digunakan adalah deskriptif korelatif, dengan pendekatan case control, sampel 114 responden yang terbagi menjadi kelompok kasus 57 dan kelompok kontrol 57, analisa uji bivariat menggunakan chi-square.

Hasil penelitian status gizi sebagian besar balita kurus dan setengah dari balita mengalami ISPA.

Kesimpulan terdapat hubungan antara status gizi dengan ISPA pada balita di Puskesmas Mekarwangi Garut Tahun 2018. Disarankan agar petugas kesehatan meningkatkan penyuluhan kepada masyarakat tentang faktor-faktor yang mempengaruhi ISPA agar bisa menanggulangi dan melakukan pencegahan terutama masalah perbaikan gizi.

Kata Kunci: Status Gizi, Kejadian ISPA, Balita

\section{Pendahuluan}

Perilaku masyarakat yang diharapkan dalam masyarakat sehat 2025 adalah perilaku yang bersifat proaktif untuk memelihara dan meningkatkan kesehatan, mencegah resiko terjadinya penyakit, melindungi diri dari ancaman dan masalah kesehatan lainnya, serta berpartisipasi dalam gerakan kesehatan masyarakat termasuk menyelenggarakan masyarakat sehat dan aman. Upaya kesehatan diselenggarakan dengan cara pengutamaan pada upaya pencegahan (preventif) dan peningkatan kesehatan (promotif) bagi segenap warga indonesia tanpa mengabaikan upaya penyembuhan penyakit kuratif dan pemeliharaan kesehatan (rehabilitatif) agar dapat memelihara dan meningkatkan kesehatan diperlukan pola upaya peningkatan lingkungan yang sehat (KemenKes RI, 2009).

Golden age atau masa keemasan anak merupakan masa pertumbuhan dan perkembangan otak paling cepat, dimana sel otak anak mengalami perkembangan terbaiknya. Periode ini tidak dapat diulang dan akan memberikan hasil maksimal atas apa yang diajarkan pada anak secara fisik dan psikologis. Periode emas dapat diwujudkan apabila pada rentang usia tersebut, balita memperoleh asupan gizi yang sesuai untuk tumbuh kembang yang optimal (Shantika, 2017). Usia balita lebih sering terkena penyakit dibandingkan orang dewasa, hal ini disebabkan sistem pertahanan tubuh pada balita terhadap penyakit infeksi masih dalam tahap perkembangan. Salah satu penyakit infeksi yang paling sering di derita oleh balita adalah (ISPA) infeksi saluran pernafasan akut (Syafarilla, 2011 dalam Hayati 2014).

World Health Organization menyebutkan insiden infeksi saluran pernapasan akut (ISPA) dengan angka kematian balita diatas 40 per 1000 kelahiran hidup atau 15\% - $20 \%$ pertahun pada balita (WHO, 2014). Di Indonesia kasus ISPA masih menempati urutan pertama penyebab kematian pada kelompok bayi dan balita dengan prevalensi $25 \%$ dengan morbiditas gizi kurang $14,9 \%$, sedangkan di Jawa Barat prevalensi ISPA adalah 
20\%. Prevalensi gizi kurang/gizi buruk dijawa barat juga masih cukup tinggi yaitu $13,9 \%$ gizi kurang dan $3,0 \%$ gizi buruk (RISKESDAS, 2013). Status gizi merupakan faktor resiko penting terjadinya ISPA, status gizi buruk akan membuat sistem kekebalan tubuh menurun dan meningkatkan resiko terjadinya penyakit infeksi.

Data Dinas Kesehatan Kabupaten Garut menyebutkan ISPA merupakan penyakit terbanyak ke 2 dengan jumlah 106.310 kasus atau sebanyak 15,64\%. Morbiditas gizi buruk sebanyak 0,32\% dan 0,84 gizi kurang (Dinkes Kab Garut, 2016). Angka kejadian ISPA terbanyak terdapat di Puskesmas Mekarwangi yaitu sebanyak 8004 kasus atau $16,87 \%$ dan pada

balita sebanyak 1840 kasus atau $14,63 \%$ dan Prevalensi gizi kurang (kurus) yaitu sebanyak 104 kasus atau $47,06 \%$, dan gizi buruk (sangat kurus) 1 kasus.

Balita adalah anak yang berumur 0-59 bulan dimana pada masa ini semua akan kebutuhan aktivitas tergantung penuh pada orang tua mulai dari makan, minum, buang air besar, buang air kecil, kebersihan diri dan yang lainnya (Marimbi, 2010). Status gizi balita merupakan ukuran keberhasilan dalam pemenuhan kebutuhan nutrisi untuk anak, dalam hal ini perhatian orang tua sangat diperlukan untuk proses tumbuh kembang. Indikator status gizi merupakan tanda-tanda yang dapat memberikan gambaran tentang keadaan keseimbangan antara asupan dan kebutuhan gizi oleh tubuh. Keadaan kurang gizi dapat menyebabkan beberapa penyakit seperti TBC, diare kronis, campak dan penyakit infeksi lainnya (Savhita, Nandeeshwara, Kumar, 2007). Hal ini didukung oleh penelitian yang dilakukan (Madanijah, 2014) bahwa terdapat hubungan status gizi masa lalu dan partisipasi ibu di posyandu dengan kejadian tuberkulosis.

ISPA (infeksi saluran pernapasan akut) adalah infeksi akut yang melibatkan organ saluran pernapasan atas dan saluran pernapasan bagian bawah, infeksi ini disebabkan oleh virus, jamur dan bakteri (Marni, 2014). Faktor resiko terjadinya ISPA yaitu umur, jenis kelamin, status gizi, BBLR, pemberian ASI, status imunisasi, defisiensi Vit $A$, lingkungan dan faktor perilaku (Sukman, 2014). Bila penyakit ISPA tidak bisa tersembuhkan dalam 2 minggu maka infeksi akan berlanjut ke paru-paru yang menyebabkan pneumonia (peradangan paruparu). Komplikasi lain yang mungkin terjadi di antaranya bronkhitis, pneumonia, otitis media, sinusitis, gagal napas, cardiac arrest, syok, serta dapat mempengaruhi proses tumbuh kembang anak seperti berat badan tidak normal dan kecakapan otak tidak maksimal (Depkes RI, 2010).

ISPA lebih sering menyerang pada balita dikarenakan asupan makanan yang tidak seimbang yang akan mempengaruhi status gizi anak tersebut. Dalam keadaan gizi yang baik, tubuh mempunyai cukup kemampuan untuk mempertahankan diri terhadap penyakit infeksi, sedangkan jika keadaan gizi yang buruk, maka reaksi kekebalan tubuh akan menurun sehingga kemampuan tubuh untuk mempertahankan diri dari serangan infeksi pun akan menurun. Hal ini di dukung oleh Maya Dkk (2015) yang menyatakan bahwa terdapat hubungan status gizi dengan penyakit infeksi. Berdasarkan hasil studi pendahuluan terhadap 10 orang balita yang menderita ISPA didapatkan 6 orang balita yang berumur 5 tahun mempunyai berat badan rata-rata $14 \mathrm{~kg}$ dan 4 balita lainnya mempunyai berat badan rata-rata $20 \mathrm{~kg}$.

\section{Metode}

Jenis penelitian dalam penelitian ini adalah deskriftip korelatif. penelitian deskriftif korelatif yaitu jenis penelitian yang menggambarkan ada atau tidaknya hubungan dan apabila ada hubungan seberapa erat apa hubungan tersebut, serta ada arti atau tidaknya hubungan tersebut. Adapun desain penelitian menggunakan case control. (Arikunto, 2013)

Variabel dalam penelitian ini terdiri dari variabel independen dan dependen/variabel independen dalam penelitian ini yaitu status gizi dan variabel dependen yaitu kejadian ISPA.

Populasi pada penelitian ini adalah semua anak usia 0-5 tahun yang berobat ke Puskesmas Mekarwangi Garut. Jumlah sampel pada penelitian ini berjumlah 114 responden yang di bagi menjadi 2 kelompok yaitu 57 responden untuk kelompok kasus (responden yang mempunyai penyakit ISPA) dan 57 responden untuk kelompok kontrol (responden yang bukan ISPA). Cara pemilihan sampel dalam penelitian ini adalah non probability 
sampling, dimana tehnik pengambilan sampel menggunakan consecutive sampling yang merupakan pengambilan anggota sampel dari semua subjek yang datang dan memenuhi kriteria pemilihan dimasukan dalam penelitian sampai jumlah subjek yang dibutuhkan terpenuhi (Oktavia, 2015).

\section{Hasil \& Pembahasan}

\section{Status Gizi}

Berdasarkan hasil penelitian status gizi pada balita pada kelompok kasus (ISPA) sebagian besar dari responden mempunyai status gizi kurang (kurus) yaitu 30 orang $(52,6 \%)$ dan pada kelompok kontrol (bukan ISPA) hampir seluruh responden mempunyai status gizi baik (normal) yaitu 51 orang (89,5\%).

Status gizi adalah keadaan tubuh sebagai akibat konsumsi makanan dan penggunaan zat-zat gizi. Dibedakan antara status gizi buruk (sangat kurus), gizi kurang (kurus), gizi baik (normal) dan gizi lebih (gemuk), (Almatsier, 2012). Berdasarkan tabel 1 diatas dapat diketahui bahwa status gizi balita pada kelompok kasus sebagian besar dari responden mempunyai status gizi kurang (kurus) yaitu 30 orang $(52,6 \%)$ dan pada kelompok kontrol hampir seluruh responden mempunyai status gizi baik (normal) yaitu 51 orang (89,5\%). Banyaknya balita yang mempunyai gizi kurang (kurus) disebabkan karena faktor asupan gizi, gizi yang dikonsumsi anak tidak seimbang dan memang anak malas makan (Maryunani, 2010).

Anak dibawah 5 tahun sangat rentan mengalami gangguan pertumbuhan dan perkembangan. Pertumbuhan (growth) berkaitan dengan kondisi fisik seperti berat badan dan tinggi badan sedangkan perkembangan berkaitan erat dengan sifat dan kemampuan seseorang. Hal ini disebabkan karena usia ini merupakan masa golden age yang sangat berpengaruh bagi anak dalam tumbuh kembangnya. Untuk mengoptimalkan pertumbuhan dan perkembangan dalam masa golden age ini anak memerlukan asupan gizi yang baik (Shantika, 2017).

Sulistioningsih (2011) mengatakan gizi sangat dibutuhkan oleh tubuh, status gizi menentukan kesehatan tubuh. Balita merupakan kelompok yang rentan terhadap masalah gizi, dimana pada kelompok tersebut paling mudah menderita gangguan kesehatan yang biasanya berhubungan dengan proses kehidupan manusia. Pada kelompok tersebut berada pada suatu siklus pertumbuhan dan perkembangan yang memerlukan zat-zat gizi dengan jumlah yang lebih besar dari kelompok umur yang lain.

Gizi yang baik dikombinasikan dengan kebiasaan makan yang sehat. Pengaturan makanan yang seimbang menjamin terpenuhinya kebutuhan gizi untuk energi, pertumbuhan anak, melindungi anak dari penyakit dan infeksi serta membantu perkembangan mental dan kemampuan belajarnya. Oleh sebab itu, bila kekurangan zat gizi akan terjadi gangguan kesehatan. Zat gizi adalah ikatan kimia yang diperlukan tubuh untuk melakukan fungsinya, yaitu menghasilkan energi, membangun dan memelihara jaringan, serta mengatur prosesproses kehidupan (Fatimah, 2008).

Sebagaimana diungkapkan Ahmad (2013) status gizi dibagi menjadi 4 yaitu gizi baik untuk over weight, termasuk kegemukan dan obesitas, gizi baik untuk well nourished, gizi kurang untuk under weight yang mencakup mild dan Moderate Protein Calori Malnutrition dan gizi buruk untuk severe PCM, termasuk marasmus, marasmus-kwashiorkor dan kwashiorkor. Kebutuhan akan zat makanan tergantung kepada usia, jenis kelamin, dan beban kerja. Zat makanan yang dibutuhkan tubuh meliputi keseluruhan zat gizi, yang paling sesuai adalah makanan seimbang. Kebutuhan zat gizi diperoleh melalui pola makan yang baik, sehat dan juga menu yang seimbang. Menu seimbang adalah menu yang terdiri dari beraneka ragam makanan

Tabel 1 | Distribusi frekuensi dan persentase responden berdasarkan Status Gizi balita di Puskesmas Mekarwangi Garut

\begin{tabular}{|c|c|c|c|}
\hline \multicolumn{2}{|c|}{ Karakteristik Responden } & $\begin{array}{c}\text { Jumlah } \\
\text { (n) }\end{array}$ & $\begin{array}{c}\text { Persentase } \\
\text { (\%) }\end{array}$ \\
\hline \multicolumn{4}{|l|}{ ISPA } \\
\hline \multirow{7}{*}{ Bukan ISPA } & Kurus & 30 & 52,6 \\
\hline & Normal & 27 & 47,4 \\
\hline & Jumlah & 57 & 100,0 \\
\hline & & & \\
\hline & Kurus & 6 & 10,5 \\
\hline & Normal & 51 & 89,5 \\
\hline & Jumlah & 57 & 100,0 \\
\hline
\end{tabular}


dalam jumlah dan proporsi yang sesuai sehingga memenuhi kebutuhan gizi balita guna pemeliharaan dan perbaikan sel-sel tubuh dan proses kehidupan serta pertumbuhan dan perkemangan (Sulistyoningsih, 2011).

\section{Kejadian ISPA}

Berdasarkan hasil penelitian bahwa setengah dari responden mengalami ISPA yaitu sebanyak 57 orang $(50 \%)$ dan setengahnya lagi tidak mengalami ISPA yaitu sebanyak 57 orang (50\%). Banyak nya balita yang mempunyai penyakit ISPA disebabkan karena adanya faktor resiko yaitu banyak nya anak yang mempunyai status gizi kurang (kurus).

Infeksi saluran pernapasan akut (ISPA) adalah infeksi saluran pernapasan akut yang menyerang organ tenggorokan, hidung dan paru-paru yang berlangsung kurang lebih 14 hari, ISPA mengenai struktur saluran di atas laring, tetapi kebanyakan penyakit ini mengenai bagian saluran atas dan bawah secara stimulan atau berurutan (Muttaqin, 2008). Terdapat beberapa faktor resiko yang mempengaruhi terjadinya ISPA yaitu faktor individu anak meliputi (umur, jenis kelamin, status gizi, berat bayi lahir rendah (BBLR), pemberian ASI, status imunisasi dan defisiensi vitamin $A$ ), lingkungan dan faktor perilaku (Depkes, 2010).

ISPA lebih sering menyerang bayi dan balita dikarenakan sistem kekebalan nya masih rentan dan penyakit infeksi mudah menyerang terutama ISPA (Prabowo, 2012). Hal ini sesuai dengan penelitian Fibrila (2015) bahwa terdapat perbedaan antara jumlah penderita ISPA Pada Balita Dan Dewasa.

\section{Hubungan Status Gizi Dengan Kejadian ISPA}

Hasil uji Chi-square tentang Hubungan Status Gizi Dengan Kejadian ISPA pada balita di Puskesmas Mekarwangi Garut Tahun 2018, di peroleh hasil $p$ value $=0,000$ maka Ho ditolak yang berarti ada hubungan antara status gizi dengan kejadian ISPA pada balita di Puskesmas Mekarwangi Garut Tahun 2018. Dari perhitungan odds ratio diperoleh nilai OR sebesar 9,444, hal ini menunjukan bahwa balita dengan status gizi kurus memiliki resiko 9,444 kali mengalami infeksi saluran pernapasan akut (ISPA) di banding dengan balita yang mempunyai status gizi normal.

Status gizi adalah keadaan tubuh sebagai akibat konsumsi makanan dan penggunaan zat-zat gizi. Dibedakan antara status gizi buruk (sangat kurus), gizi kurang (kurus), gizi baik (normal) dan gizi lebih (gemuk) (Almatsier, 2012). Infeksi saluran pernapasan akut (ISPA) adalah infeksi yang menyerang organ tenggorokan, hidung dan paruparu yang berlangsung kurang lebih 14 hari, ISPA mengenai struktur saluran di atas laring, tetapi kebanyakan penyakit ini mengenai bagian saluran atas dan bawah secara stimulan atau berurutan (Muttaqin, 2008).

Hasil penelitian menunjukan bahwa hampir setengahnya balita yang mengalami ISPA mempunyai status gizi kurang (kurus) dan hampir seluruh balita yang tidak mengalami ISPA mempunyai status gizi yang baik (normal). Berdasarkan hasil uji bivariat dengan uji Chi-square dinyatakan ada hubungan status gizi dengan kejadian ISPA pada balita di Puskesmas Mekarwangi Garut Tahun 2018, dengan hasil $p$ value 0,000 dan nilai OR sebesar 9,444 hal ini menunjukan bahwa balita dengan status gizi kurus memiliki resiko 9,444 kali mengalami infeksi saluran pernapasan akut (ISPA) di banding dengan balita yang mempunyai status gizi normal.

Tabel 2 | Distribusi Frekuensi dan Persentasi Kejadian ISPA pada balita di Puskesmas Mekarwangi Garut

\begin{tabular}{lcc} 
Kategori & Frekuensi & Persentase (\%) \\
\hline ISPA & 57 & 50,0 \\
Bukan ISPA & 57 & 50,0 \\
\hline Jumlah & 114 & 100.0
\end{tabular}

Tabel 3 | Hubungan Status Gizi dengan Kejadian ISPA pada balita di Puskesmas Mekarwangi Garut

\begin{tabular}{lcccccc}
\multirow{2}{*}{ Karakteristik } & \multicolumn{9}{c}{ Kejadian } & \multirow{2}{*}{ P Value } & Odds Ratio \\
\cline { 2 - 5 } & ISPA & $\%$ & Bukan ISPA & $\%$ & & \\
\hline Kurus & 30 & 52,6 & 6 & 10,5 & 0,000 & 9,444
\end{tabular}


Sulistyoningsih (2011) mengatakan bahwa status gizi merupakan salah satu faktor penyebab terjadinya ISPA hal ini dibuktikan dengan hasil penelitian Hayati (2014) bahwa status gizi merupakan salah satu faktor yang dapat menyebabkan penyakit ISPA. Keadaan gizi sangat berpengaruh pada daya tahan tubuh. Anak yang gizi nya kurang atau buruk (badannya kurus) akan lebih mudah terjangkit penyakit menular atau penyakit infeksi. Penelitian Savhita, Nandeeshwara, Kumar (2007) menyatakan bahwa keadaan malnutrisi berpengaruh pada proporsi ISPA pada balita. Dan menurut Marmi dan Kukuh (2012) dalam Darmayanti (2014) anak yang makan tidak cukup baik, maka daya tahan tubuhnya dapat melemah sehingga mudah terserang penyakit infeksi.

Berdasarkan teori Almatsier (2009), kurangnya asupan nutrisi dan penyakit infeksi mempunyai hubungan yang saling timbal balik. Anak yang kurang asupan nutrisinya maka akan mengakibatkan daya tahan tubuh menurun sehingga mudah terkena penyakit infeksi terutama ISPA. Sebaliknya penyakit infeksi derajat apapun dapat memperburuk keadaan gizi. Anak yang memiliki penyakit infeksi akan menyebabkan menurunnya kemampuan tubuh dalam mengabsorpsi zat-zat yang dibutuhkan tubuh untuk perbaikan jaringan yang rusak, membentuk sel-sel baru dan sumber energi tidak tersedia secara adekuat. Dampak lain dari penyakit infeksi adalah penggunaan energi yang berlebihan dari tubuh untuk mengatasi penyakit bukan untuk pertumbuhan dan perkembangan, sehingga akan mengganggu pertumbuhan dan perkembangan tubuh anak.

Status gizi pada anak sangat penting, karena status gizi yang baik akan meningkatkan daya tahan tubuh dan kekebalan tubuh anak, sehingga anak tidak akan mudah terkena penyakit infeksi. Semakin rendah status gizi balita maka semakin rendah pula daya tahan tubuh balita, maka semakin rentan untuk terinfeksi dan sebaliknya, bila konsumsi gizi pada seseorang tidak seimbang akan terjadi malnutrisi (overnutrition atau undernutrition), penelitian prajapati (2009) menyatakan bahwa berat badan balita memiliki hubungan yang signifikan terhadap kejadian ISPA.
Oleh karenanya untuk mencegah terjadinya ISPA, maka harus dilakukan peningkatan kesehatan seperti perbaikan gizi, imunisasi dengan cara mengatur pola makan yang seimbang dan perbaikan lingkungan pemukiman (Sulistyoningsih, 2011).

\section{Kesimpulan}

Berdasarkan hasil penelitian dapat disimpulkan bahwa sebagian besar status gizi balita mempunyai gizi yang kurang (kurus), setengah dari balita mengalami ISPA, terdapat hubungan status gizi dengan kejadian ISPA pada balita, terdapat peluang status gizi kurus terhadap terjadinya ISPA pada balita di Puskesmas Mekarwangi Garut Tahun 2018.

\section{Bibliografi}

1. Keputusan menteri kesehatan republik indonesia. 2010. Standar antropometri penilaian status gizi anak. Melalui < http://gizi.depkes.go.id>[23/12/2017].

2. Shantika, Ebi 2017. Golden Age Parenting. Yogyakarta: Psikologi Corner.

3. Hayati, Sri. 2014. Gambaran Faktor Penyebab Infeksi Saluran Pernapasan Akut (Ispa) Pada Balita Di Puskesmas Pasirkaliki Kota Bandung.[20/12/2017].

4. World Health Organization. 2014. World health statistic. Di ambil dari http://search.who.int/search [5/12/2017]

5. Riset Kesehatan Dasar (RisKesDas). Badan Penelitian Dan Pengembangan Kesehatan Kementrian RI Tahun 2013. Melalui <http://www.depkes. Go.id> [20/12/2017].

6. Dinas Kesehatan Kabupaten Garut. 2016. Profil Kesehatan garut.

7. Marimbi. H, 2010. Tumbuh Kembang Status Gizi Dan Imunisasi Dasar Pada Balita. Yogyakarta: Nuha Medika.

8. Savhita, MR, Nandeeshwara SB, Kumar MJP. 2007 Modificable Risk factors for acute respiratory tract infection. Indian J Pediatr 74:477-82.

9. Madanijah, Siti. 2007. Hubungan antara status gizi masa lalu anak dengan partisipasi ibu di posyandu dengan kejadian tuberkulosis pada murid taman kanak-kanak. Melalui http://download.portalgaruda.org>[10/01/2018].

10. Marni. 2014. Asuhan Keperawatan Pada Anak Sakit Dengan Gangguan Pernapasan. Yogyakarta: Gosyen Publishing. 
11. Sukman, Putra. 2014. Kapita Selekta kedokteran. Jakarta: Media Aesculapius

12. Departemen Kesehatan RI. 2010. Pedoman Pengendalian Penyakit Infeksi Saluran Pernafasan Akut.[20/12/2017].

13. Arikunto. 2013. Manajemen penelitian. Jakarta : Rineka Cipta.

14. Oktavia, Nova. 2015. Sistematika Penulisan Karya IImiah. Yogyakarta: Budi Utama.

15. Maryunani. Anik. 2010. IImu Kesehatan Anak Dalam Kebidanan. Jakarta: CV. Trans Info Media.

16. Sulistyoningsih, Hariyani. 2011. Gizi Untuk Kesehatan Ibu dan Anak. Yogyakarta. Graha IImu.

17. Fatimah, Sari. 2008. Faktor-Faktor Yang Berkontribusi Terhadap Status Gizi Pada Balita Di Kecamatan Ciawi Kabupaten Tasikmalaya. melalui <http://download.portalgaruda.org>[10/01/2011].

18. Ahmad, G. 2011. Imunisasi Mengapa Perlu?Cetakan 1. Jakarta: Penerbit Karya.

19. Mutataqin, Arif. 2008. Buku Ajar Askep Klien Dengan Gangguan Sistem Pernafasan. Jakarta: Salemba Medika.

20. Prabowo. 2012. Definisi ISPA pada balita. http://prabowo-9879-7-

referensiassyariabdullah.blogspot.com-2008-04-15definisi-dan-jenis-jenis-ISPApada-balita.html. [25 Juli 2018]

21. Fibrila, Firda. 2015. Hubungan Usia Anak, Jenis Kelamin dan Berat Badan Lahir Anak Dengan Kejadian ISPA. Jurnal Kesehatan Metro Sai Wawai Volume VIII No. 2 Edisi Des 2015, ISSN : 19779-469X.

22. Almatsier, Sunita. 2012. Prinsip Dasar IImu Gizi. Jakarta: Gramedia Pustaka Umum.

23. Darmayanti. 2014. Hubungan Status Imunisasi Dengan Kejadian ISPA pada Balita di Puskesmas Cempaka Banjar Baru.[19/07/2018].

24. Almatsier, S.2009. Prinsip Dasar IImu Gizi. Jakarta: Gramedia Pustaka.

25. Prajapati, Bipin. 2009. A Study Of Risk Factors Of Acute Respiratory Tract Infection (ARI) Of Under Five Age Group In Uban And Rural Communities Of Ahmedabad District, Gujarat. Healthline Edisi ISSN 2229-337X Volume 3. 